\title{
Retrofitting of Columns of an Existing Building by RC, FRP and SFRC Jacketing Techniques
}

\author{
Pranay Ranjan ${ }^{1}$, Poonam Dhiman ${ }^{2}$ \\ ${ }^{1,2}$ (Department of Civil engineering, Jaypee University of Information Technology, Waknaghat, Solan,HP.)
}

\begin{abstract}
The objectives of this paper is to design RC, FRP and SFRC Jacketing of failed columns of an existing building and to compare suitability of these three methods of retrofitting. The presented work also describes design procedure of Reinforced Concrete, Carbon Fibre Reinforced Polymer Jacketing and Steel Fibre Reinforced Polymer Jacketing for strengthening an existing columns. There is a large world-wide need for simple and reliable methods to repair and strengthen aging infrastructure and buildings. The use of FRP Jacketing offers several advantages over the RC and SFRC Jacketing but it is slightly expensive.
\end{abstract}

Keywords - Concrete Jacketing, FRP Jacketing, SFRC Jacketing, Retrofitting.

\section{INTRODUCTION}

Jacketing of columns consists of added concrete with longitudinal and transverse reinforcement around the existing columns. This type of strengthening improves the axial and shear strength of columns while the flexural strength of column and strength of the beam-column joints remain the same. It is also observed that the jacketing of columns is not successful for improving the ductility. A major advantage of column jacketing is that it improves the lateral load capacity of the building in a reasonably uniform and distributed way and hence avoiding the concentration of stiffness as in the case of shear walls. This is how major strengthening of foundations may be avoided. In addition, the original function of the building can be maintained, as there are no major changes in the original geometry of the building with this technique. Jacketing of columns is needed when the load carried by the column is increased due to either increasing the number of floors or due to mistakes in the design. Jacketing is practiced when the compressive strength of the concrete or the percent and type of reinforcement are not according to the codes' requirements and also when columns is exposed to an earthquake, an accident such as collisions, fire, explosions.

The most common types of jackets are steel jacket, reinforced concrete jacket, fibre reinforced polymer composite jacket, jacket with high tension materials like carbon fibre, glass fibre etc.

\subsection{Problem Statement}

The building that is considered for this work has been modelled in STADD PRO software. This residential building is situated in Patna, Bihar. This building is initially designed to be built upto 4 storey in approx 2000 sq. feet . For its foundation there are 22 Live piles which are 9 meter deep in the soil and 9 Dead piles which are 7 meter deep in the soil. It has 31 tie beams of dimension $0.300 \mathrm{~m} \times 0.300 \mathrm{~m}$. It has 5 rooms, 4 bathrooms, a store room , a dining hall, a drawing hall, a kitchen, and with 4 balconies for each room. Room sizes are $3.66 \mathrm{~m}$ by $3.35 \mathrm{~m}$, size of dining hall is $3.20 \mathrm{~m}$ by $6.55 \mathrm{~m}$ and that of drawing hall is $6.55 \mathrm{~m}$ by $3.35 \mathrm{~m}$, bathroom size are $2.44 \mathrm{~m}$ by $1.52 \mathrm{~m} \& 1.52 \mathrm{~m}$ by $1.52 \mathrm{~m}$. Kitchen has a dimensions of $3.2 \mathrm{~m}$ by $2.13 \mathrm{~m}$. Its columns sizes are of $\quad 0.3 \mathrm{~m} \times 0.3 \mathrm{~m}, \quad 0.36 \mathrm{~m} \times 0.3 \mathrm{~m}$, and $0.4 \mathrm{~m} \times 0.3 \mathrm{~m} \quad \&$ beams are of $0.3 \mathrm{~m} \times 0.25 \mathrm{~m}, 0.3 \mathrm{~m} \times 0.3 \mathrm{~m}$, $0.25 \mathrm{~m} \times 0.25 \mathrm{~m}, 0.36 \mathrm{~m} \times 0.3 \mathrm{~m}$. slab has a thickness of 5 inch i.e $0.125 \mathrm{~m}$. For the present work, $(\mathrm{G}+3)$ storey building with storey height 3 meter for all, with plan $18 \mathrm{mx} 9 \mathrm{~m}$ is taken. Buildings has bays in irregular form in both X \& Y axis. For this 4 storey building, load was applied as per IS code 1875:1987 (Part 2), to show that no column failed for 4 storey. And as we increase the storey of building by 1 storey, then it's 6 columns failed due to increase in load. And as we modelled this building to 6 storey, it's 19 columns failed, only at ground and first floor level.

- As existing building was modelled as per cross-section of columns provided and load applied \& analyse in Stadd Pro V8i and found that till 4 storey there is no any deficient (failed) columns (as shown in fig1) because initially building was designed as per 4 storey.

- As we model 5 storey,some of columns (six columns) of building failed. Columns(highlighted) that fails are $63,64,74,79,80$ are of cross-section $300 \mathrm{~mm} \times 300 \mathrm{~mm}$ as shown in fig 2 .

- As we model 6th storey, many columns failed. Columns(highlighted) which fail are $62,63,64,65,66,67,69,70,72,73,74,77,78,79,80,179,180,189,190$ are of cross-section $300 \mathrm{~mm} \times 300 \mathrm{~mm} \&$ $400 \mathrm{~mm} \times 300 \mathrm{~mm}$ as shown in fig 3 . 


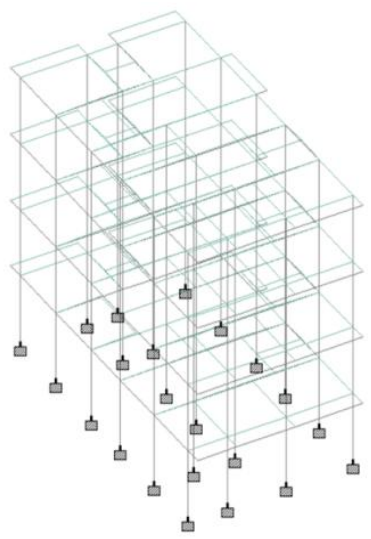

Fig 1: 4 Storey building No column failed columns fail

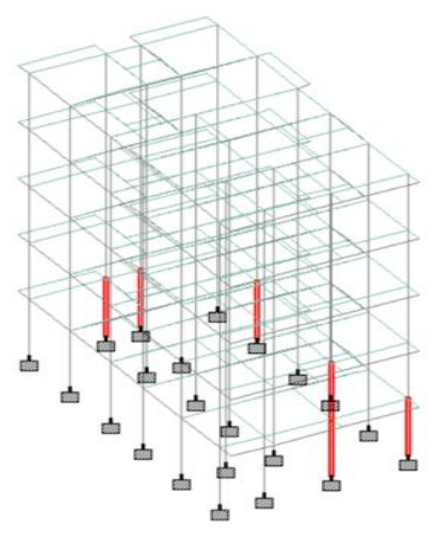

Fig 2: 5 Storey Building -6 columns failed

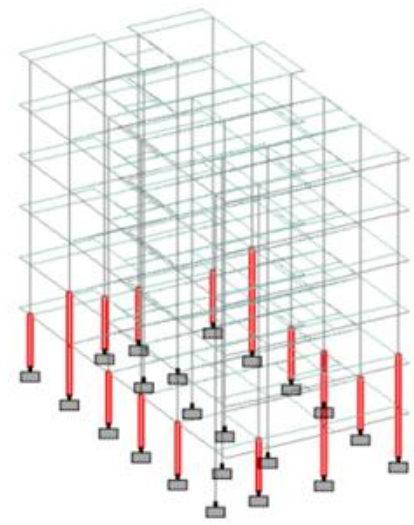

Fig 3: 6 Storey Building $-19$

\section{DESIGN OF RC JACKETING OF FAILED COLUMNS FOR 5 STOREY BUILDING}

For 5 storey building, A total of six columns failed as shown in fig 2. RC Jacketing to these columns are designed as per IS code 15988:2013.

One design example for column no 63 is given here:

\section{Column No- 63}

Height of column $=3000 \mathrm{~mm}$; Width $(\mathrm{b})=300 \mathrm{~mm}$; Reinforcement provided $=4,16 \varnothing=804.25 \mathrm{~mm}^{2}$; $\mathrm{P}=965.156 \mathrm{kN} ; \quad \mathrm{M}=15.307 \mathrm{kNm}$;

$$
\begin{array}{ll}
\text { Depth }(D)=300 \mathrm{~mm} ; & d=260 \mathrm{~mm} ; \\
f_{y}=415 \mathrm{MPa} ; & \mathrm{f}_{\mathrm{ck}}=30 \mathrm{MPa} . \\
\mathrm{P}_{\mathrm{u}}=1447.734 \mathrm{kN} ; & \mathrm{M}_{\mathrm{u}}=22.961 \mathrm{kNm}
\end{array}
$$

Since, $P u=0.4 \times f_{c k} \times A_{c}+0.67 \times f_{y} \times A_{s c}$

According to the provisions provided in to $\$ 8.5 .1 .2$ (a) of IS 15988: 2013, Concrete strength shall be at least 5 $\mathrm{MPa}$ greater than the strength of the existing concrete. Thus, taking value of $f_{c k}=35 \mathrm{~N} / \mathrm{mm}^{2}$ and assuming $A_{s c}=$ $0.8 \% \mathrm{~A}_{\mathrm{c}}$

$1447.734 \times 10^{3}=0.4 \times 35 \times \mathrm{A}_{\mathrm{c}}+0.67 \times 415 \times\left(0.8 \% \mathrm{~A}_{\mathrm{c}}\right)$;

According to $\$ 8.5 .1 .1$ (e) of IS $15988: 2013, \mathrm{~A}_{\mathrm{c}}^{\prime}=1.5 \mathrm{~A}_{\mathrm{c}}$;

Therefore, $\mathrm{A}_{\mathrm{c}}=89234.10 \mathrm{~mm}^{2}$

Assuming the cross sectional details as:

$\mathrm{B}=400 \mathrm{~mm} ; \mathrm{D}=133851.15 / 400=334.63 \mathrm{~mm}$

Jacketing details of cross section: $B=(400-300) / 2=50 \mathrm{~mm} ; \quad \mathrm{D}=(334.63-300) / 2=17.315 \mathrm{~mm}$

However, According to the code specified above, Minimum jacket thickness shall be $100 \mathrm{~mm}$ as per $\S 8.5 .1 .2$ (c) of IS 15988:2013

Thus, New size of the column: $B=300+100+100=500 \mathrm{~mm}, \quad \mathrm{D}=300+100+100=500 \mathrm{~mm}$

New concrete area $=500 \times 500=250000 \mathrm{~mm}^{2}>A_{c}=89234.10 \mathrm{~mm}^{2}$

Area of steel, $\mathrm{A}_{\mathrm{s}}=0.8 \% \times 500 \times 500=2000 \mathrm{~mm}^{2}$

But according to $\$ 8.5 .1 .1$ (e) IS 15988:2013, $A_{s}^{\prime}=(4 / 3) A_{s}=(4 / 3) \times 2000=2666.67 \mathrm{~mm}^{2}$

Assuming $16 \mathrm{~mm} \varnothing$ bars, Thus, number of bars, $N=2666.67 \times 4 /(\pi \times 162)=13.263$ bars

Therefore, 14 no. $-16 \mathrm{~mm} \varnothing$ bars is for whole sections. So, providing 10 NO. $-16 \mathrm{~mm} \varnothing$ bars for jacketed section. And jacketed section will be $500 \mathrm{~mm}$ x $500 \mathrm{~mm}$. Details of all jackets with their reinforcement details are given below in Table 1 .

Table 1 Detailing of RC Jacket for 5 storey building

\begin{tabular}{|l|l|l|l|l|l|}
\hline Column & $\mathrm{Pu}(\mathrm{kN})$ & $\mathrm{Mu}(\mathrm{kNm})$ & Jacketed & Jacketed ClS $\left(\mathrm{mm}^{2}\right)$ & Lateral Ties \\
\hline 63 & 1447.73 & 22.96 & $10-16 \varnothing$ & $500 \times 500$ & $8 \mathrm{~mm} \emptyset @ 90 \mathrm{~mm} \mathrm{c/c}$ \\
\hline 64 & 1143.31 & 33.29 & $10-16 \varnothing$ & $500 \times 500$ & $8 \mathrm{~mm} \emptyset @ 90 \mathrm{~mm} \mathrm{c/c}$ \\
\hline 74 & 1213.04 & 27.63 & $10-16 \varnothing$ & $500 \times 500$ & $8 \mathrm{~mm} \emptyset @ 90 \mathrm{~mm} \mathrm{c/c}$ \\
\hline 79 & 1114.12 & 36.23 & $10-16 \varnothing$ & $500 \times 500$ & $8 \mathrm{~mm} \emptyset @ 90 \mathrm{~mm} \mathrm{c/c}$ \\
\hline 80 & 1113.09 & 18.01 & $10-16 \varnothing$ & $500 \times 500$ & $8 \mathrm{~mm} \emptyset @ 90 \mathrm{~mm} \mathrm{c/c}$ \\
\hline
\end{tabular}


IOSR Journal of Mechanical and Civil Engineering (IOSR-JMCE) e-ISSN: 2278-1684, p-ISSN: 2320-334X

\begin{tabular}{|l|l|l|l|l|l|}
\hline 179 & 1147.68 & 22.13 & $10-16 \varnothing$ & $500 \times 500$ & $8 \mathrm{~mm} \emptyset @ 90 \mathrm{~mm} \mathrm{c/c}$ \\
\hline
\end{tabular}

Similarly for six storey building, size of jacket is calculated as per design steps given above and given in Table $2^{-}$ for all Failed columns.

Table 2 Detailing of RC Jacket for 6 storey building

\begin{tabular}{|c|c|c|c|c|c|}
\hline Column No & $\mathrm{Pu}(\mathrm{kN})$ & $\mathrm{Mu}(\mathrm{kNm})$ & Jacketed section & Jacketed ClS & Lateral Ties \\
\hline 62 & 1281.79 & 19.23 & $10-16 \varnothing$ & $500 \times 500$ & 8mm Ø@90mm c/c \\
\hline 63 & 1701.29 & 19.75 & $10-16 \varnothing$ & $500 \times 500$ & 8mm Ø@90mm c/c \\
\hline 64 & 1379.89 & 31.79 & $10-16 \varnothing$ & $500 \times 500$ & 8mm Ø@90mm c/c \\
\hline 65 & 1489.16 & 44.46 & $10-16 \varnothing$ & $500 \times 600$ & 8mm Ø@90mm c/c \\
\hline 66 & 1155.17 & 28.48 & $10-16 \varnothing$ & $500 \times 500$ & 8mm Ø@90mm c/c \\
\hline 67 & 1176.81 & 18.02 & $10-16 \varnothing$ & $500 \times 500$ & 8mm Ø@90mm c/c \\
\hline 69 & 1529.95 & 45.01 & $10-16 \varnothing$ & $500 \times 600$ & 8mm Ø@90mm c/c \\
\hline 70 & 1249.54 & 27.32 & $10-16 \varnothing$ & $500 \times 500$ & 8mm ø@90mm c/c \\
\hline 72 & 1746.78 & 31.65 & $25-12 \varnothing$ & $500 \times 600$ & $8 \mathrm{~mm} \varnothing @ 55 \mathrm{~mm} \mathrm{c} / \mathrm{c}$ \\
\hline 73 & 1278.43 & 24.31 & $10-16 \varnothing$ & $500 \times 500$ & 8mm Ø@90mm c/c \\
\hline 74 & 1443.32 & 24.92 & $10-16 \varnothing$ & $500 \times 500$ & 8mm Ø@90mm c/c \\
\hline 77 & 1030.51 & 24.42 & $10-16 \varnothing$ & $500 \times 500$ & 8mm Ø@90mm c/c \\
\hline 78 & 1099.29 & 33.30 & $10-16 \varnothing$ & $500 \times 500$ & 8mm Ø@90mm c/c \\
\hline 79 & 1327.93 & 33.68 & $10-16 \varnothing$ & $500 \times 500$ & 8mm Ø@90mm c/c \\
\hline 80 & 1328.14 & 17.30 & $10-16 \varnothing$ & $500 \times 500$ & 8mm Ø@90mm c/c \\
\hline 179 & 1402.36 & 18.49 & $10-16 \varnothing$ & $500 \times 500$ & $8 \mathrm{~mm} \emptyset @ 90 \mathrm{~mm} \mathrm{c} / \mathrm{c}$ \\
\hline 180 & 1154.20 & 44.04 & $10-16 \varnothing$ & $500 \times 500$ & 8mm Ø@90mm c/c \\
\hline 189 & 1063.84 & 32.99 & $10-16 \varnothing$ & $500 \times 500$ & 8mm Ø@90mm c/c \\
\hline 190 & 1196.94 & 29.49 & $10-16 \varnothing$ & $500 \times 500$ & $8 \mathrm{~mm} \varnothing @ 90 \mathrm{~mm} \mathrm{c} / \mathrm{c}$ \\
\hline
\end{tabular}

\subsection{Cost of RC Jackets of column no 63}

The formula for calculation of materials for required volume of concrete is given by equation given as follows.

$$
\mathrm{V}_{\mathrm{c}}=\frac{\mathrm{W}}{1000}+\frac{\mathrm{C}}{1000 \mathrm{~S}_{\mathrm{c}}}+\frac{\mathrm{F}_{\mathrm{a}}}{1000 \mathrm{~S}_{\mathrm{ta}}}+\frac{\mathrm{C}_{\mathrm{a}}}{1000 \mathrm{~S}_{\mathrm{ca}}}
$$

Where, $\mathrm{V}_{\mathrm{c}}=$ Absolute volume of fully compacted fresh concrete $; \mathrm{W}=$ Mass of water; $\mathrm{C}=$ Mass of cement ; Fa = Mass of fine aggregates ; $\mathrm{Ca}=$ Mass of coarse aggregates; $\mathrm{S}_{\mathrm{c}}, \mathrm{S}_{\mathrm{fa}}$ and $\mathrm{S}_{\mathrm{ca}}$ are the specific gravities of cement, fine aggregates and coarse aggregates respectively.

Let, $\mathrm{Vcj}=\mathrm{Vol}$ of concrete in jacketed section $\quad ; \mathrm{V}_{\mathrm{R}}=\mathrm{Vol}$ of lateral \& tranverse reinf.

$$
\text { - Vol of reinforcement }=6.13 \times 10^{-3}+3.52 \times 10^{-3}=9.65 \times 10^{-3} \mathrm{~m}^{3}
$$

$=\left[\left(500^{2}-300^{2}\right)-\left(10 \times \pi \times 16^{2} \div 4\right)\right]=0.482 \mathrm{~m}^{3}$

Let, $\mathrm{M}_{\mathrm{R}}=$ Mass of reinf. $=7850 \mathrm{~kg} / \mathrm{m}^{3} \times 9.65 \times 10^{-3}=75.75 \mathrm{~kg}$

Consider concrete with mix proportion of 1:1.5:3 where, 1 is part of cement, 1.5 is part of fine aggregates and 3 is part of coarse aggregates of maximum size of $20 \mathrm{~mm}$. The water cement ratio required for mixing of concrete is taken as 0.45 .

Assuming bulk densities of materials

Cement $=1500 \mathrm{~kg} / \mathrm{m}^{3}$

Sand $=1700 \mathrm{~kg} / \mathrm{m}^{3}$

Coarse aggregates $=1650 \mathrm{~kg} / \mathrm{m}^{3}$
Specific gravities of concrete materials

Cement $=3.15$

Sand $=2.6$

Coarse aggregates $=2.6$.

The mix proportion of 1:1.5:3 by dry volume of materials can be expressed in terms of masses as:

Cement $=1 \times 1500=1500 \mathrm{~kg}$;

Sand $=1.5 \times 1700=2550 \mathrm{~kg}$

Coarse aggregate $=3 \times 1650=4950 \mathrm{~kg}$

Therefore, the ratio of masses of these materials w.r.t. cement will as follows $=1:(2550 / 1500):(4950: 1500)$

So, from above data, $\quad \mathrm{C}=179.15 \mathrm{~kg} ; \quad \mathrm{F}_{\mathrm{a}}=304.55 \mathrm{~kg} ; \quad \mathrm{C}_{\mathrm{a}}=591.18 \mathrm{~kg}$

$$
=1: 1.7: 3.3
$$

Therefore, cost of concrete $=$ Cost of (Cement + FA + CA + Reinf. $)$

$$
=(179.15 \div 50 \times \operatorname{Rs} 350)+(304.55 \div 1700 \times \operatorname{Rs} 882)+(591 \div 1650 \times \operatorname{Rs} 2258)=\mathrm{Rs} 2220
$$


Cost of Reinf. $=$ Rs $50 / \mathrm{kg} \times 75.75 \mathrm{~kg}=\mathrm{Rs} 3788$.

Therefore total cost of material $=$ INR 6008 .

\section{DESIGN OF FIBRE REINFORCED POLYMER JACKETING}

FRP Jacketing is used because Carbon fibre is flexible and can be made to contact the surface tightly for a high degree of confinement due to its high strength and high modules of elasticity. The use of FRP in strengthening solutions has become an efficient alternative to some of the existing traditional methods due to some advantages such their features in terms of strength, lightness, corrosion resistance and ease of application. Such techniques are also most attractive for their fast execution and low labour costs. FIB Model Code for concrete Structures 2010 is the code which is used in the design of FRP Jacketing.

\subsection{Design of FRP Jacketing of Failed column no-63}

The given dimensions are, $\mathrm{b}=300 \mathrm{~mm}, \mathrm{~d}=260 \mathrm{~mm}$;

$\mathrm{f}_{\mathrm{ck}}$ provided $=30 \mathrm{Mpa} ; \quad \mathrm{f}_{\mathrm{ck}}$ required $=35 \mathrm{Mpa}$,

$\mathrm{Pt} \%$ provided $=0.8 \%$ of $\mathrm{A}_{\mathrm{c}}=720 \mathrm{~mm}^{2}$,

Area of concrete $=89280 \mathrm{~mm}^{2}, \quad \mathrm{Pu}=1447.734 \mathrm{kN}, \quad \mathrm{Mu}=22.961 \mathrm{kNm}$

Data provided from manufacturer for jacket is as follows :

Ultimate strain in carbon fibre $\left(\varepsilon_{\mathrm{f}}\right)=1.5 \%$;

Elastic modulus of carbon fibre $\left(\mathrm{E}_{\mathrm{f}}\right)=137000 \mathrm{~N} / \mathrm{mm}^{2}$;

Effectively Confined Core for Non Circular Section

Total Plan Area of Unconfined concrete is obtained as per FIB (2010).

$b^{\prime}=b-2 \times r_{c}=300-2 \times 25=250 \mathrm{~mm} ; \quad r_{c}=$ Radius of rounded corners of column

$\mathrm{d}^{\prime}=\mathrm{d}-2 \times \mathrm{r}_{\mathrm{c}}=260-2 \times 25=210 \mathrm{~mm}$

$\mathrm{Au}=\left(\mathrm{b}^{2}+\mathrm{d}^{2}\right) \div 3=35533.33 \mathrm{~mm}^{2}$

The confinement effectiveness coefficient $k_{e}$ considering ratio $\left(A_{c}-A_{u}\right) / A_{c}$ as per Fib $14 \mathrm{eq}^{\mathrm{n}} 6.29$ is given as, $\mathrm{K}_{\mathrm{e}}=1-\left[\left(\mathrm{b}^{2}+\mathrm{d}^{\prime 2}\right) /\left\{3 \mathrm{~A}_{\mathrm{g}}\left(1-\rho_{\mathrm{sg}}\right)\right\}\right]=0.602 ; \quad \rho_{\mathrm{sg}}=\mathrm{A}_{\mathrm{s}} / \mathrm{A}_{\mathrm{g}}$

The Lateral confining pressures induced by the FRP wrapping as per Fib eqn 6.30 is given as

Along direction $b$,

$\mathrm{K}_{\text {confb }}=\rho_{\mathrm{b}} \mathrm{k}_{\mathrm{e}} \mathrm{E}_{\mathrm{f}}$

Along direction $\mathrm{d}$,

Where, $\rho_{\mathrm{b}}=2 \mathrm{ntf} / \mathrm{b}=0.0044 ;$ and $\rho_{\mathrm{d}}=2 \mathrm{ntf} / \mathrm{d}=0.0051$

$\mathrm{K}_{\text {confd }}=\rho_{\mathrm{d}} \mathrm{k}_{\mathrm{e}} \mathrm{E}_{\mathrm{f}}$

$\mathrm{K}_{\text {confb }}=362.89 ; \mathrm{K}_{\text {confd }}=420.62$

Effective confining pressure, along direction $\mathrm{b}$;

$\mathrm{f}_{\mathrm{lb}}=\left(\mathrm{K}_{\text {confb }} \times \varepsilon_{\mathrm{f}}\right) / 2 \mathrm{~K}_{\mathrm{e}}=4.52 \mathrm{~N} / \mathrm{mm}^{2}$

Taking min value: $\mathrm{f}_{1}=4.52 \mathrm{~N} / \mathrm{mm}^{2}$

Along direction d
$\mathrm{f}_{\mathrm{ld}}=\left(\mathrm{K}_{\text {confd }} \times \varepsilon_{\mathrm{f}}\right) / 2 \mathrm{~K}_{\mathrm{e}}=5.24 \mathrm{~N} / \mathrm{mm}^{2}$

Maximum confining pressure as per equation 6.5 of FIB, which is given as,

$\mathrm{f}_{\mathrm{cc}}=\mathrm{f}_{\mathrm{c}}^{\prime}\left[2.254 \sqrt{ }\left(1+7.94 \mathrm{f}_{\mathrm{l}} / \mathrm{f}_{\mathrm{c}}^{\prime}\right)-2 \mathrm{f}_{\mathrm{l}} / \mathrm{f}^{\prime} \mathrm{c}-1.254\right]$

$\mathrm{f}_{\mathrm{cc}}=53.552 \mathrm{~N} / \mathrm{mm}^{2}$

"Hence provide 2 layer of CFRP jacket."

Cost of FRP Jackets is around Rs2600 - Rs4600 per $\mathrm{m}^{2}$

And area to be jacketed $=3.65 \mathrm{~m}^{2}$

So, total cost of FRP Jacket per column(2 layer)= INR 18980

All columns for $5 \& 6$ storey posses same cost per column.

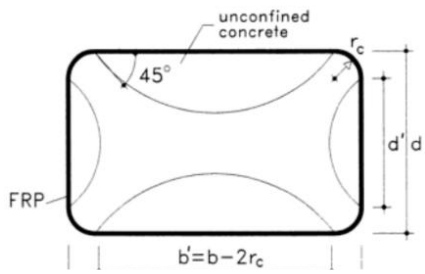

Fig4: Effective confined core for non circular

\section{DESIGN OF STEEL FIBRES REINFORCED CONCRETE JACKETS}

During recent years, steel fibre reinforced concrete has gradually advanced from a new, rather unproven material to one which has now attained acknowledgement in numerous engineering applications. Lately it has become more frequent to substitute steel reinforcement with steel fibre reinforced concrete. Steel Fibres are generally distributed throughout a given cross section whereas reinforcing bars or wires are placed only where required. Steel fibres are relatively short and closely spaced as compared with continuous reinforcing bars of wires. It is generally not possible to achieve the same area of reinforcement to area of concrete using steel fibres as compared to using a network of reinforcing bars of wires. Steel Fibres are typically added to concrete in low volume dosages (often less than 1\%), and have been shown to be effective in reducing plastic shrinkage cracking. It do not significantly alter free shrinkage of concrete, however at high enough dosages they can increase the resistance to cracking and decrease crack width. Steel Fibres in Concrete can improve Crack, Impact, Fatigue Resistance, Shrinkage Reduction, Toughness. Benefits of SFRC is that it distributed localized stresses, Reduces maintenance and repair cost and Resistance to freezing and thawing. 


\subsection{Design of SFRP Jacketing of Failed column no-63}

$\mathrm{b}=300 \mathrm{~mm} ; \mathrm{d}=300 \mathrm{~mm}$; Effective cover of column $\mathrm{a}=40 \mathrm{~mm}$

Steel reinforcement $(2,16 \varnothing)$ in the compression zone of cross sectional area(As') $=402.12 \mathrm{~mm}^{2}$

Steel reinforcement $(2,16 \varnothing)$ in the tensile zone of cross sectional area(As) $=402.12 \mathrm{~mm}^{2}$

And, their yielding point, $\mathrm{f}_{\mathrm{y}}=210 \mathrm{MPa}$;

After rehabilitation, the column will have to undergo an axial force, $\mathrm{F}=1447.73 \mathrm{kN}$ and a bending moment,

$\mathrm{M}=22.96 \mathrm{kN} . \mathrm{m}$. The column cannot support these efforts without strengthening.

The design column height $\left(\mathrm{H}_{0}\right)=3.05 \mathrm{~m}$.

Solution.

Let us choose the strengthening materials: Steel fibre

Compressive strength $\left(\mathrm{f}_{\mathrm{c}^{\prime} \text { ad }}\right)=17.72 \mathrm{MPa} ;$ Tensile strength $\left(\mathrm{f}_{\mathrm{t}}\right)=1.37 \mathrm{MPa}$;

Ultimate compressive $\operatorname{strain}\left(\varepsilon_{\mathrm{u}}\right)=0.00337$

The factor defining the intensity of compressive stress on the equivalent rectangular stress block for fibre reinforced concrete, $\mathrm{Y}_{\mathrm{f}}=0.85+0.03(\mathrm{WL} / \mathrm{D}) / 450 \leq 0.88 \quad$;Where WL/D is the percentage of steel fibres by weight. In this case, $\bigvee_{\mathrm{f}}=0.861$ is taken.

Additional steel reinforcing bars in the jacket: $\mathrm{A}_{\mathrm{s} \text { ad }}{ }^{\prime}=\mathrm{A}_{\mathrm{s} \text { ad }}$;

$\mathrm{f}_{\mathrm{y} \text { ad }}=280 \mathrm{MPa}$.

For this design, rectangular stress block is to be used.

Let us assume the thickness of the $\operatorname{SFRC}(t)=150 \mathrm{~mm}$.

The sizes of the strengthened element are, $\quad b^{\prime}=b+2 t=600 \mathrm{~mm} ; \quad d^{\prime}=d+2 t=600 \mathrm{~mm}$

Loading eccentricity about centroid of the cross section $(\mathrm{e})=\mathrm{M} / \mathrm{F}=15.85 \mathrm{~mm}$

Loading eccentricity about centroid of the additional steel reinforcement in the tension zone of the cross section, $\mathrm{e}=\mathrm{e}_{\mathrm{o}}+0.5 \mathrm{~d}^{\prime}-\mathrm{a}=275.85 \mathrm{~mm}$

Projection of all forces on the longitudinal axis of the column $\sum X=0$ gives:

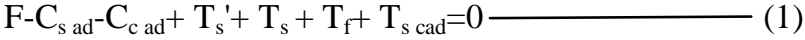

Where the resultant force in the additional compression and in the tension reinforcing steel bars,

$\mathrm{C}_{\mathrm{s} \text { ad }}=28 \mathrm{~A}_{\mathrm{s}}{ }^{\prime}=28 \mathrm{~A}_{\mathrm{s}}=\mathrm{T}_{\mathrm{s} \text { ad }}=11259.36 \mathrm{~mm}^{2}$

The resultant force in the compression fibre concrete, $C_{c \text { ad }}=\gamma_{f} f_{c}{ }^{\prime}$ ad $b^{\prime}(x)=9154.15 x$.

The resultant force in the existing tension reinforcing steel, initially working in the compression zone,

$\mathrm{T}_{\mathrm{s}}{ }^{\prime}=\mathrm{f}_{\mathrm{y}} \mathrm{A}_{\mathrm{s}}{ }^{\prime}=210 \times 402.12=84.45 \mathrm{kN}$

The resultant force in the existing tension steel, $\mathrm{T}_{\mathrm{s}}=\mathrm{f}_{\mathrm{y}} \mathrm{A}_{\mathrm{s}}=210 \times 402.12=84.45 \mathrm{kN}$

The resultant force in the tension fibre concrete, $\mathrm{T}_{\mathrm{f}}=\mathrm{f}_{\mathrm{t}} \mathrm{b}^{\prime} \mathrm{d}=1.37 \times 600 \times 150=123.3 \mathrm{kN}$

By replacing the forces by their respective values in the equation (1), the depth of the equivalent rectangular stress block is calculated as, $\mathrm{x}=190.07 \mathrm{~mm}$.

Taking moments of all forces and equating to zero gives:

Fe- $\mathrm{C}_{\mathrm{sad}}\left(\mathrm{d}^{\prime}-2 \mathrm{a}\right)-\mathrm{C}_{\mathrm{cad}}\left(\mathrm{d}^{\prime}-0.5 \mathrm{x}-\mathrm{a}\right)+\mathrm{T}_{\mathrm{s}}^{\prime}(\mathrm{d}+\mathrm{t}-2 \mathrm{a})+\mathrm{T}_{\mathrm{s}} \mathrm{t}+\mathrm{T}_{\mathrm{f}}(0.5 \mathrm{t}-\mathrm{a})=0$

The following calculations indicate that the additional steel reinforcing bars are not needed. However the design code requires in this case a minimum reinforcement, the amount of which depends on the ratio $\mathrm{H}_{\mathrm{o}} / \mathrm{H}$.

Since, $\mathrm{H}=(\sqrt{3} / 6) \mathrm{d}^{\prime}=173.21 \mathrm{~mm} \Rightarrow \mathrm{H}_{\mathrm{o}} / \mathrm{H}=17.6$

Consequently, the reinforcement cross sectional area required by the code

$\mathrm{A}_{\mathrm{s} \min }=0.1 \% \mathrm{~b}^{\prime}\left(\mathrm{d}^{\prime}-\mathrm{a}\right)=336 \mathrm{~mm}^{2} \Rightarrow$ We take $3,12 \varnothing$

Let us check the resistance condition:

$\mathrm{Fe} \leq \mathrm{C}_{\mathrm{sad}}\left(\mathrm{d}^{\prime}-2 \mathrm{a}\right)+\mathrm{C}_{\mathrm{cad}}\left(\mathrm{d}^{\prime}-0.5 \mathrm{x}-\mathrm{a}\right)-\mathrm{T}_{\mathrm{s}}{ }^{\prime}(\mathrm{d}+\mathrm{t}-2 \mathrm{a})-\mathrm{T}_{\mathrm{s}} \mathrm{t}-\mathrm{T}_{\mathrm{f}}(0.5 \mathrm{t}-\mathrm{a})$

$399.35 \mathrm{kN} . \mathrm{m}<741.29 \mathrm{kN} . \mathrm{m}$

(Since, $\mathrm{C}_{\mathrm{Cad}}=\mathrm{\gamma}_{\mathrm{f}} \mathrm{f}_{\mathrm{cad}} \mathrm{b}^{\prime} \mathrm{x}=9154.15 \mathrm{x}=1739.93 \mathrm{kN}$ )

Obviously, the flexural strength of the column is sufficient after the strengthening by the S.F.R.C.

Hence, Jacket of thickness $(\mathrm{t})=150 \mathrm{~mm}$.

4.2 Cost of SFRC Jackets of column no 63

Vol. of concrete used in Jacketing $=(150 \mathrm{~mm} \times 300 \mathrm{~mm} \times 3050 \mathrm{~mm}) \times 4=0.549 \mathrm{~m}^{3}$

Vol. of reinforcement used in jacketing $=7850 \mathrm{~kg} / \mathrm{m}^{3} \times 0.000336 \times 3.05=8.04 \mathrm{~kg}$

Cost of reinforcement used in jacketing=Rs50 $\times 8.04=$ Rs 402

Cost of concrete used in jacketing derived similar as done

in section $2.1=$ Rs 2530 


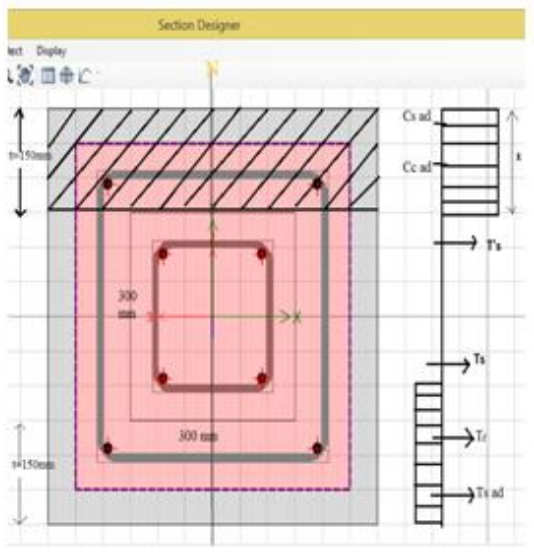

Since, Cost of SFRC in the market is Rs 20000-Rs 60000/ton

Cost of SFRC used in jacketing=

$(1 \%$ of concrete used in jackets $) \times 7900 \mathrm{~kg} / \mathrm{m}^{3} \times \mathrm{Rs} 20=\mathrm{Rs} 867.42$

So, total cost of SFRC $=$ Rs 3800

\section{CONCLUSION}

The following table shows a detailed comparison of RC, FRP and SFRC Jacketing.

Table 3: Comparison of RC,FRP and SFRC Jacketing

\begin{tabular}{|c|c|c|c|}
\hline & RC Jacketing & FRP Jacketing & SFRC Jacketing \\
\hline $\begin{array}{l}\text { Minimum } \\
\text { width of } \\
\text { Jacket }\end{array}$ & $\begin{array}{l}\text { - Width of jackets used is } 100 \\
\text { mm which will reduce carpet } \\
\text { area of building. }\end{array}$ & $\begin{array}{l}\text { - Width of jackets used is } \\
0.66 \mathrm{~mm} \text { which is very less } \\
\text { and will not pose any changes } \\
\text { in carpet area of building. }\end{array}$ & $\begin{array}{l}\text { - Width of jackets used is } 150 \\
\text { mm which is even more than } \\
\text { RC Jacketing. }\end{array}$ \\
\hline $\begin{array}{l}\text { Properties } \\
\text { of Jacket }\end{array}$ & $\begin{array}{l}\text { - Match with the concrete of } \\
\text { the existing structure. } \\
\text { - Compressive strength greater } \\
\text { than that of the existing } \\
\text { structures by } 5 \mathrm{~N} / \mathrm{mm}^{2} \text { or at } \\
\text { least equal to that of the } \\
\text { existing structure. }\end{array}$ & $\begin{array}{l}\text { - Completely different with } \\
\text { that of existing structure. } \\
\text { - Compressive strength is } \\
\text { greater than that of existing } \\
\text { structures by } 5 \mathrm{~N} / \mathrm{mm}^{2} \text { or } \\
\text { equal to that of the existing } \\
\text { structure. }\end{array}$ & $\begin{array}{l}\text { Match with that of RC as } \\
\text { well as FRP Jacketing } \\
\text { because } \\
\text { reinforcement, and steel fibre } \\
\text { are used. }\end{array}$ \\
\hline $\begin{array}{l}\text { Cost of } \\
\text { Jacket }\end{array}$ & - INR 6000 per column & - INR 18900 per column & - INR 3800 per column \\
\hline $\begin{array}{l}\text { Factored } \\
\text { Load and } \\
\text { Moment }\end{array}$ & $\begin{array}{l}\text { Factored load is only used for } \\
\text { the design of RC Jacketing. }\end{array}$ & $\begin{array}{l}\text { - Neither Factored load nor } \\
\text { moment is used for the design } \\
\text { of RC Jacketing. }\end{array}$ & $\begin{array}{l}\text { - Factored load as well as } \\
\text { moment is only used for } \\
\text { design of RC Jacketing. }\end{array}$ \\
\hline
\end{tabular}

In addition to above, the following can also be concluded:

1. In RC Jacketing, sizes of the sections are increased and the free available usable space becomes less and also huge dead mass is added.

2. In RC Jacketing, drilling of holes in existing column, slab, beams and footings are required which cause further damage to the columns.

4. $\mathrm{RC}$ retrofitting technique are significant improvement in Moment resisting capacity, shear strength capacity in Beam and Axial load carrying capacity in column.

5. FRP Jacketing is costlier as compared to RC \& SFRC Jacketing but better than RC and SFRC jacketing.

7. Confinement by FRP Jackets enhanced the performance of concrete columns.

\section{REFERENCES}

[1] IS 15988:2013, Seismic Evaluation And Strengthening Of Existing Reinforced Concrete Buildings -Guidelines, Bureau of Indian Standards, New Delhi, 2013.

[2] IS 875:1987(Part 2), Design Loads For Buildings And Structures- BIS, New Delhi, 1987.

[3] IS 1893:1987(Part 2),Code Of Practice For Design Loads for Buildings and Structures (earthquake)- BIS, New Delhi, 1987. 
[4] IS 456:2000,Plain and Reinforced Concrete, Bureau of Indian Standards, New Delhi, 2000.

[5] Design and Detailing of RC Jacketing for Concrete Columns Nikita Gupta, Poonam Dhiman, Anil Dhiman, AETM, 2015.

[6] Materials And Jacketing Technique For Retrofitting Of Structures, Shri. Pravin B. Waghmare, International Journal of Advanced Engineering Research and Studies,2011.

[7] Handbook on Externally Bonded FRP Reinforced for RC Structures by FIB Federation.

[8] Analysis \& Design of R.C.C. Jacketing for Buildings-Vedprakash C. Marlapalle, P. J. Salunke, N. G. Gore

[9] FIB Model Code For Concrete Structures, Design of FRP Jacketing-2010.

[10] Strengthening of a reinforced concrete column by SFRC, by P Nibasumba, Tsinghua University, China,2001. 